\title{
On the Mistranslation of Daraba in the Holy Quran
}

\author{
Bouchra Qorchi \\ Faculty of Humanities, University Hassan II, Ain Chock- CASABLANCA, Morocco \\ E-mail: qorchibouchra@yahoo.fr
}

Doi:10.7575/aiac.alls.v.8n.1p.176

URL: http://dx.doi.org/10.7575/aiac.alls.v.8n.1p.176
Received: 04/11/2016

Accepted: 29/01/2017

\begin{abstract}
Improper, or literal translations of the Quran may be one of the reasons behind misinterpretations of this sacred text. This paper deals with translations of one of the most controversial verses in the Quran, one that has brought about a great deal of misunderstanding about Islam and the status of women in this religion. It is verse 34 of Surah Annissae (the surah of Women). In this verse, according to many translators, God ordered men to beat their wives. In this paper, I will try to show that beat, hit or strike are just some of a hord of meanings that the root drb (from which the verb daraba is derived) has, and that it is not necessarily this meaning that the Holy Quran intends to convey in this surah.
\end{abstract}

Keywords: daraba, Quran, women, Verse34, surah annissae, Sunnah, Prophet, separate, mistranslations, meanings

\section{Introduction}

Since the first translation of the Holy Quran into English directly from Arabic by George Sale (Al Koran, 1734), there have appeared more than sixty other translations by Muslim and non-Muslim translators ( E.H. Palmer, 1880 ; J.M. Rodwell, 1876 ; Richard Bell ,1937; Arthur J. Arberry, 1955; M. Pickthall, 1930 ; Muhammad Assad, 1980 ;Sayed Hussain Nasr, 2015 ; Talal Itani, 2012 ;Ahmed Ali, 1988 ; Abdallah Yusuf Ali, 1934 ; Aicha Bewley, 2011 ; Laleh Bakhtiar,2007 (the first woman translator of the H.Q. into English) ; N.J. Dawood, 1956 ; Abdelhaleem Muhammad, 2004, etc..).

But most of the above translations were literal ones which did not take into account the variety of meanings that a word might have. Since the object of this study is the translation of Surah 4:34 in The Holy Quran and more particularly the translation of daraba in this surah, I found out that the majority of the above-mentioned authors rendered the meaning of daraba with either beat (Shakir), beat lightly (Ahmed Ali), hit (M.A.S. Abdelhaleem), scourge (Pickthall) or strike (Abdullah Yusuf Ali).

Translating the Holy Quran into English poses many interpretational problems. Many English translations of the Quran have been widely criticised for their inability to capture the intended meaning (e.g. Ali,1992 ;Alkhawalda,2004 ;Ardekani,2002 ;Shaki,2000).

There is agreement among Muslim scholars that the Holy Quran cannot be transferred literally to another language (Ushama, 1995 : 130). This is due to several reasons :

1) Words of different languages do not express all the shades of meaning of their counterparts, though they may express specific concepts.

2) Narrowing down the meaning of the Holy Quran to specific concepts in foreign languages would mean missing out other important dimensions.

3) The presentation of the H.Q. in different languages would result in confusion and misguidance.

It is true that no literary masterpiece is ever fully translatable into another language, let alone the Holy Quran, a divine book revealed to the prophet Mohammed (peace be upon him) and accepted as the last scripture for human guidance by Muslims.

This does not mean that the H.Q. should not be translated, though it loses much in tone

And nuance, let alone the incommunicable beauty, grandeur and grace of the original.

How could a text which, in the memorable words of A. J. Arberry (1964, cover page), is « neither prose nor poetry but a fusion of both » ever reveal its mysteries via translation in another language?

But since the majority of Muslims in the world are non-Arabic speakers, it, indeed, makes it a necessity to deal with the Quran in many languages . Translators of sacred texts, however, tend to stick more closely to the original than translators of other types of composition (Devin J. Stewart, $2000: 31-48$ ). The result, in most cases, is a literal translation devoid of meaning where metaphoric expressions are sacrificed for the sake of reproducing the original syntax. As Omar Cheikh Alshabab (2003 : 21) states, «one of the reasons compelling translators for studying the Quran is the fact that each translation bears witness to the conscious and determined effort of the translator, which means that 
there is no general consensus on which meanings of the Quran are closest or best, each one has his or her own reasons for preferring or rejecting a particular translation $»$.

In this paper, I will try to shed some light on some mistranslations made by some scholars while trying to render the meaning of the Quran into English, and I will put more emphasis on translations of the root drb in the Holy Quran. The corpora used in this paper are taken mainly from the Holy Quran and the Sunnah (Prophet's tradition).

\section{A controversial verse}

Verse 34 of surah annisae (women) had been targeted on many occasions. Of all the Quranic passages about men and women, it is ,perhaps, the one most often misunderstood verse.In this verse, it is believed God allowed men to beat their wives in case of نشوز (disobedience), but neither the instrument to be used for the punishment (hand or something else) nor the part of the body to be beaten are mentioned in this verse, as will be noticed from its English translation :

«Men are (meant to be righteous and kind) guardians of women because God has favored some more than others and because they (men) spend out of their wealth.(In their turn), righteous women are (meant to be) devoted and to guard what God has (willed to be) guarded even though out of sight (of the husband). As for those you fear ill-will and nasty conduct, admonish them (first), next leave them alone in beds, and (last) beat or separate them from you. » $(3: 34)$

In the Arabic language,generally, the verb $\square \square$ is used for a slap on the face, and $\square \square$ is used for a slap on the backneck, and وكز is used for a punch, whereas $y$ is used for a kick.But nothing of this is specified in $4: 34$.

We all know of cases where a simple slap on the face was enough to lead to blindness or a hard stroke on the head could lead to death. So, how could such violence be attributed to God in the absence of any evidence (precision)?

We notice that, in Verse 2 of Surah Annour ( $D$ 莯

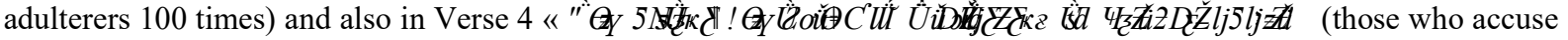
innocent women of adultery without bringing four witnesses, then flog them 80 flogs », the Quranic text didn't use daraba to denote physical punishment, it rather used jalada (lash, whip, flog). So, how could a text which is so specific (mentions even the number of whips) neglect specifying the kind of beating and the part to beaten in $4: 34$ if it were meant to be understood in the sense of hit, beat or strike?

Let us compare this with Verse 41-44 In Surah Ayyub (38) : «And take in your hand a bundle of thin grass and strike therewith your wife and break not your oath. »

So, here, we can see how Prophet Ayyub was informed about how to resolve the dilemma in which he was because of the oath he made when he was sick to punish his wife upon recovery. The Quranic text instructs Ayyub to satisfy his oath by hitting his wife with a handful of fragrant grass. The objective was to satisfy the promise without harming the wife. Here,the Quranic text has specified the tool for the 'punishment' which is not the case in $4: 34$.

If verse $4: 34$ is singled out by some to be the most controversial verse in the Quran, it is, I believe, partly due to mistranslations and partly due to the neglect of sunna (prophet's tradition) in interpretation and also because of the myriad of meanings that the root drb might invoke.

\section{Daraba : a multi-meaning word}

In the Quran Dictionary (on line), it is mentioned that the root drb occurs 58 times in the Quran, 55 times as verb and 3 times as noun. And among the meanings of the verb daraba, we find travel, set forth, go forth, put forth, cast, present, set up, take away, put up, leave, etc..

Verbal idioms are a significant component of the Quranic vocabulary; they occur quite frequently, so that clusters of verbal idioms are sometimes found within the span of a short passage.

The verb daraba derived from the root (drb) is probably one of the most diversely used idiomatic verbs, not only in the Quran, but also in the Arabic language, including Moroccan Arabic (B.Qorchi, 2011). This verb is often used figuratively; it is rarely used with the meaning of beat or strike except when the instrument that served the beating or the part of the body (or thing) to be beaten are mentioned, as is the case in the following verses :

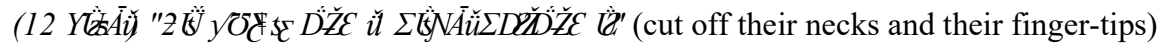

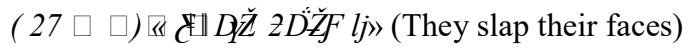

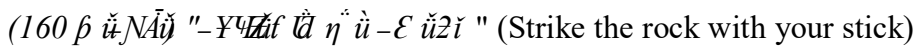

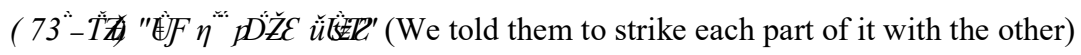

$$
\begin{aligned}
& \text { As for verse }(37: 93) \text { : }
\end{aligned}
$$

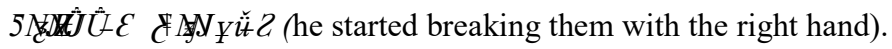

it is said that Abraham started breaking the idols made and worshipped by Quraysh . So,here, even strike, that most translators use to render the meaning of drb, is inadequate because we cannot imagine Abraham striking idols with the right hand as this act would cause him more harm than relief.

As mentioned earlier, the verb daraba can mean travel, set out $(3: 156,4: 101,38: 44,73: 20,2: 273)$; strike $(2: 60 / 73,7: 160,8: 12,20: 77,24: 31,26: 63,37: 93,47: 4)$; beat $(8: 50,47: 27)$; set up $(43: 58,57: 13)$; give examples $(14: 24 / 45,16: 75,76: 112,18: 32 / 45,24: 35,38: 28 / 58,36: 78,39: 27 / 29,43: 17,59: 21$, $66: 10 / 11)$; take 
away, ignore $(43: 5)$; condemn $(2: 61)$; seal,draw over $(18: 11)$; cover $(24: 31)$; explain $(13: 17)$; separate, turn away $(3: 34)$.

According to Edward William lane (1868: 1775), the preposition?an is not actually necessary to render the verb daraba as turn away, separate, etc.. Edward Lane, here, does not use his own knowledge of Arabic to give definitions to the words, instead, the definitions are taken from older Arabic dictionaries, such as Taj Al Arus (Shaykh Muhammad Almurtada, 1791) and the Misbah (Al Feiyoumi ,1987), etc... He, then, translated these definitions into English, carefully noting which dictionaries are giving which definitions.

In this way, اضربوهن in verse 34 of Surah Annissae can mean turn away or separate, even in the absence of the preposition?an. This certainly seems the understanding of earlier Classical Arabic lexicon authorities that were scrutinised and cited by Edward Lane.

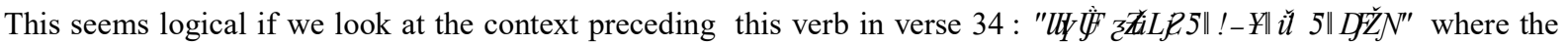
use of climactic order, that is from the least to the most important, indicates graduality : first advise them, if not, then, turn away from them (in bed). What seems more logical as the next step is separate from them, because beating them doesn't follow the tradition (sunnah) of step-by-step or attadarruj that the prophet (pbuh) was preaching. Beating, here, doesn't follow the logic of argumentation. If we consider that the general theme of the verses is to offer reconciliatory ways that would save marriage and not violence that would probably worsen the situation and which is more likely to breach the union.. The Quranic text has been so careful and so precise in the formulation of the second step to be taken by saying :

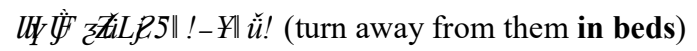

There is no indication in the prophet's tradition (sunnah) that beating a woman is allowed, and the prophet (pbuh) was never reported to have beaten one of his wives. And even in situations of conflict, he used to quit home for a certain amount of time in order to allow his wives to ponder upon the issue and maybe review their behaviour or attitude.

We cannot separate the Holy Quran from the Sunnah since the Sunnah, not only explains the HQ, but it also completes

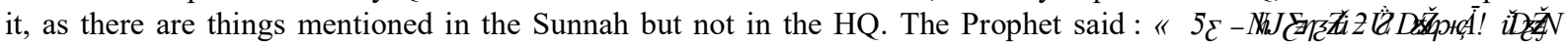

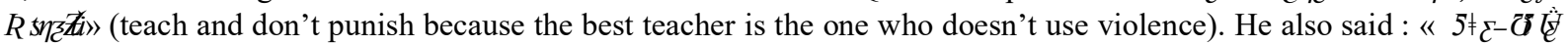

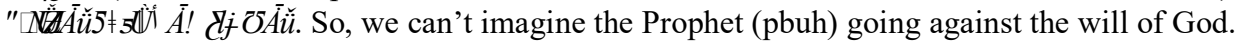

As has been shown above, the verb اضربوهن in 4:34 can mean shun or turn away from, not necessarily beat, and it does not necessarily need the preposition ?an for this meaning to be operative. It was also noted that the imperative form has not been used in the Quran in an unqualified manner without explaining 1) what object to use to strike with or 2) what part of the body or object to strike.

We do find in the Holy Qoran many uses of daraba with the meaning of separate. The following verses illustrate this meaning:

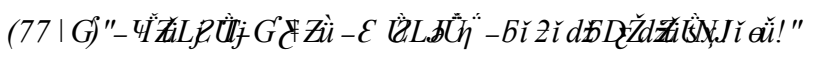

We inspired Moses to travel with my servants and separate the sea ( create a dry path for them to go through).

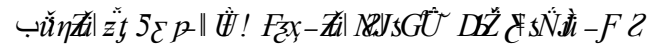

$$
\begin{aligned}
& \text { 13日9 }
\end{aligned}
$$

They were separated by a wall.....

So, as God said in 39:18: «those who listen to what they are told and follow the best of its meaning, those are the ones whom God has guided and those are the ones endowed with understanding. "

One should take the most consistent rendering in light of the Quran's narratives and overarching philosophy, i.e. the best meaning possible.

The verbs beat or strike in English have many similar figurative meanings : one may strike a metaphor, strike out on a journey, say something striking or beat about the bush, beat one's brains, beat a record,etc.. And all of these uses are idiomatic.

The verb beat in English, that some translators (Yusuf Ali, 1934 ; Shakir,1987; Al Hilali \& Mohsein Khan, 1996 ; T.B. Irving, 1985 ; Muhammad Sarwar, 1981; Abdulmajid Daryabadi, E.H. Palmer, 1880 ; Muhammad Ayoub Khan, Mahmud Y. Yazid, 1980 ; Muhammad Asad, 1980) used to render the meaning of daraba in verse 34, means 'hit repeatedly (especially with a stick)' (Oxford Advanced Learner's Dictionary of Current English).

Even Abdelahaleem Muhammad, A.S. (2004), an Arabic-speaking Muslim who has been living in England since 1966 and who has full command of English and is fully equipped with the knowledge of both Classical and Modern Arabic,

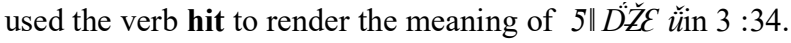

« Husbands should take good care of their wives, with the bounties God has given some to some more than others and with what they spend out of their own money. Righteous wives are devout and guard what God would have them guard in their husbands' absence. If you fear high-handedness from your wives, remind them (of the teachings of God), then ignore them when you go to bed, then hit them. » ( The Quran. A new translation, p. 54)

Needless to point to the extreme contrast between should take care of their wives and hit them in this translation. 
Webster's Dictionary gives fourteen meanings of the verb strike : hit (against), ignite, (of snake) bite, (of plants) (cause to) take root, attack, hook (fish), sound (time), as bell in clock, affect, arrive at, come upon, enter mind of, discover (oil,gold,etc..), dismantle, remove, make (coin), cease work as protest or to make demands. The same dictionary gives eight meanings of the verb beat : strike repeatedly, overcome, surpass, stir vigorously with striking action, flag (wings), make, wear (path), throb, sail against wind.

Other translators, such as Rodwell (1876), used the verb scourge to render the meaning of idribuhunna. Scourge, or flog, means beat severely with a whip (OED). " Could any of you beat your wife as he would a slave and lie with her in

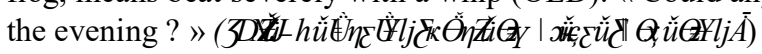

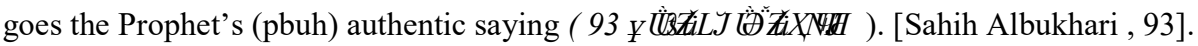

This behaviour goes against the tradition of the Prophet (pbuh) who was always urging men to take care of women as he

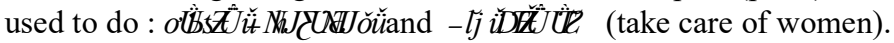

In Arab dictionaries (such as Al-Munjid), उD危5 him, and

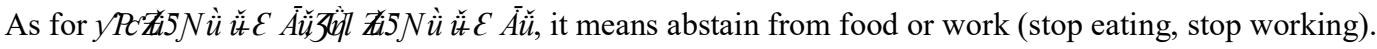

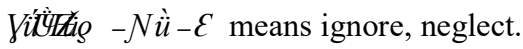

In the Holy Quran we find also $y$ /

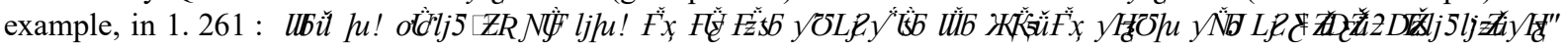
"IXN (those who spend their money for the sake of God are like a grain which gives birth to seven crops .....).

Here we have a comparison between those who spend their money for the sake of God and a grain that gives birth to seven crops so as to convey the idea that charity for the sake of God pays much more that one expects.

But in $y / z$ 范 $-\varepsilon$ as in :

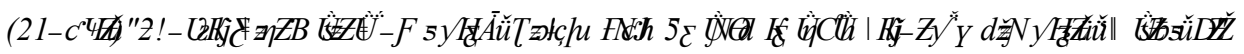

(If we expose the Quran to a mountain, it is going to collapse in respect to God).

we have a comparison between two opposed states of the mountain : its magnificence on the one hand and its humility face to its creator, on the other.Here, the example is given in order to separate the two states of the mountain to show how everything in this universe is under the mercy of God.

When we encounter a multi-meaning word, such as daraba, hit or strike, we select the proper meaning according to the context, form and common sense. And this is exactly what is meant by "Ibx above).

\section{Discussion}

Though many English translations give an explicit negative interpretation of daraba in 4:34, some contemporary scholars, such as Laleh Bakhtiar (2007), suggest "go away" as a meaning for daraba. Her interpretation is based on the premise that the Prophet (pbuh) never caused harm to any of his wives. She also argues that the commonly-given translations contradict with Verse 2:231 where men are urged to well-treat women after divorce. Haddad (2000) says that it is incorrect to assume that Islam allows wife-beating, and he mentions the Pilgrimage Sermon of the Prophet where he insisted that women be well-treated. Abou Al Fadl (2006) mentions the fact that daraba can cover a wide range of meanings in the same way as beat in English. The punishment for him should be symbolic and should not leave any marks on the body.

It is evident from the above discussion that contemporary scholars are against rendering the meaning of daraba in 4:34 with beat since this goes against the spirit of the Quranic use of this verb. The verse with its three-step program is a reform over the violent practices of seventh century Arabia and in no way a licence for battery.

\section{Conclusion}

To conclude, I should say that there is no warrant, in Verse 34 of Surah an-Nissae in the Holy Quran, for wife battering. There is, therefore, «absolutely no licence for the type of regular and continuous wife-beating that goes on in some homes. » (Qawama in Arabic legal discourse, p127). Tabari (1992, Vol. 4 :70) and Razi (1990, Vol. 10 :93) say that the beating should be symbolic and not really physical (with the use of a scarf or a miswak), but it seems absurd how such a behaviour could stop a wife's rebellion. In his discussion of $\Varangle \dot{U} 3$ (marriage), Shahid al Thani (al masalik) defines the

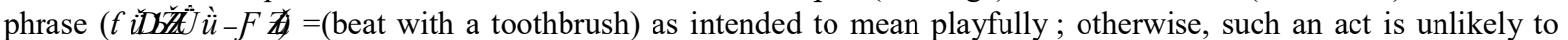
chastise or encourage reform. Bahrani (Al Hada'iq, V22,p. 618) confirms « it is not striking with a whip or stick, and there must be no bodily injury as a result ». Imam arrida, in the course of explaining the verse, states : «It is a friendly, playful strike ».

There are other interpretations (Abu Shaqah, 1994 ; Al-banna, 1997) that permit wife-beating but with safe measures.

The meaning of 'beat' attributed to daraba in $3: 34$, with all the implications that this verb suggests, would certainly not be the most appropriate rendition not only argued linguistically, but also in light of the Holy Quran's overarching philosophy of mutual respect and love. 


\section{References}

Abdel Haleem, M.A.S. (2004), The Quran : A New Translation, Oxford University Press : U.K..

Abou Al Fadl, K. (2006). The search for beauty in Islam: A conference of the books. Lanhaur, M.D.: Rowan \& Littlefield.

Abu Shaqah, A.H. (1994). Tahrir almara fi asr al risala (Women's Liberation in the Times of the Message). Kuwait : Dar al Qalam lilnashr wa al tawzi'.

Al Banna, J. (1997).Al mara almuslima bin tahrir al Quran wa taqid alfuqaha (The Muslim woman between the liberation of the Quran and the restrictions of the religious leaders). Cairo, Egypt : Dar Al fikr al Islami.

Al-Fayyumi, Ahmed bnu Ali (1987).Al Misbah Al Munir. Lebanon Library : Lebanon.

Ali, S.S.(1992).'Misinterpretation of some ellipted structures in the translation of the Quran'. Meta 3, 487-490.

Al-Khawalda, M.(2004). 'The deterioration of the usage of 'kaana' in the Holy Quran via translation',. Babel 50 (3), 215-229.

Arberry, A.J. (1985), The Koran interpreted, Oxford University Press : Oxford.

Asad, M. (1980), The Message of the Quran. Dar al Andalus : Gibraltar.

Bewly, Aicha \& Abdelhaqq (2011), The Noble Quran.A new rendering of its meaning, Bookwork : London.

Cheikh Alshabab, Omar (2003), 'The evolution of translation culture : Translating the Holy Quran into French' in Lang \& Trans. Vol.15,7/2, 1422

Dawood, N.J.,(1955), The Koran . Pengouin : London.

Haddad, G.F. (2000). Living Islam: questions and answers. Http://www.abc.se/m9783/fiqhi fiqha_e32. Nt ml.

Laleh Bakhtiar (2007), The Sublime Quran. Kazi Publications Inc. : USA.

Lane, Edward (1968), Lane's Lexicon. Librairie du Liban, Beirut : Lebanon.

Pickthall, M. Marmaduke (1953), The Meaning of the Glorious Koran. Mentor: N.Y.

Rodwell, J.M., The Koran, Everyman : London.

Sale, George (1734), Koran, commonly called the Alcoran of Mohammed.Trans. into English immediately from the original Arabic, with explanatory notes, Ackers : London.

Shakir, A. (2000).'Sound and sight effect in Quranic translation'. Perspectives : Studies in translatology 8 (1), 47-64.

Shakir, M.H. (1997), The Quran, Elmhurst : N.Y.

Stewart, Devin J. (2000), 'Understanding the Quran in English : Notes on translation, form and prophetic typology' in Diversity in language: Contrastive studies in Arabic and English theoretical and applied linguistics, Edited by Zeinab Ibrahim, Nagwa Kasbgy and Sabiha Aydelott. Cairo : The American University in Cairo Press.

Ushama, Thamem (1995), Methodologies of the Quranic Exegesis. A.S. Noordeen : Kuala Lumpur.

Yusuf Ali, A. (1989). The holy Quran : Text, Translation and Commentary. Brentwood, MD : Amana.

Yusuf Ali, A. (1992). The meaning of the Holy Quran (4th edition). Washington : Amana Corporation. 